Abstracta Iranica Abstranica

Revue bibliographique pour le domaine irano-aryen

Volume 28 | 2007

Comptes rendus des publications de 2005

\title{
Ismaili Literature. A Bibliography of Sources and Studies, London/New York, I.B. Tauris/The Institute of Ismaili Studies, 2004, $469 \mathrm{p}$.
}

Ève Feuillebois-Piérunek

\section{(2) OpenEdition}

1 Journals

\section{Édition électronique}

URL : http://journals.openedition.org/abstractairanica/12452

DOI : 10.4000/abstractairanica. 12452

ISSN : 1961-960X

Éditeur :

CNRS (UMR 7528 Mondes iraniens et indiens), Éditions de l'IFRI

\section{Édition imprimée}

Date de publication : 15 mai 2007

ISSN : 0240-8910

\section{Référence électronique}

Ève Feuillebois-Piérunek, « Ismaili Literature. A Bibliography of Sources and Studies, London/New York, I.B. Tauris/The Institute of Ismaili Studies, 2004, 469 p. », Abstracta Iranica [En ligne], Volume 28 | 2007, document 264, mis en ligne le 18 septembre 2007, consulté le 25 septembre 2020. URL : http:// journals.openedition.org/abstractairanica/12452; DOI : https://doi.org/10.4000/abstractairanica. 12452

Ce document a été généré automatiquement le 25 septembre 2020.

Tous droits réservés 


\section{Ismaili Literature. A Bibliography of Sources and Studies, London/New York, I.B. Tauris/The Institute of Ismaili Studies, 2004, 469 p.}

Ève Feuillebois-Piérunek

1 Voici un ouvrage de référence qui fera date dans l'histoire des études ismaéliennes. L'A., fort de trois décennies de recherche sur le domaine, fournit une bibliographie annotée très complète des études ismaéliennes: sources primaires ismaéliennes ou extérieures, études sur l'histoire et la pensée ismaélienne, thèses sélectionnées, etc.

Dans le premier chapitre, l'A. retrace les grandes lignes de l'histoire de l'ismaélisme et présente les principales sources primaires qui l'éclairent. Cette partie est basée sur l'ouvrage de l'A., The Ismailis: Their History and Doctrines, Cambridge, 1990. Dans le second chapitre, il donne une vue d'ensemble des études sur l'ismaélisme.

\section{INDEX}

Thèmes : 7. Islam

\section{AUTEURS}

ÈVE FEUILLEBOIS-PIÉRUNEK

Sorbonne Nouvelle - Paris III 